\title{
PENGARUH TEKNIK AFIRMASI TERHADAP TINGKAT STRESS KERJA PERAWAT COVID 19
}

\author{
Indra Frana Jaya KK ${ }^{1)}$, Irfannuddin ${ }^{2)}$, Budi Santoso ${ }^{2)}$ \\ ${ }^{1}$ RSUD Siti Fatimah Provinsi Sumsel \\ ${ }^{2}$ Fakultas Kedokteran Universitas Sriwijaya \\ Email :Indrafranajayakk48@gmail.com
}

\begin{abstract}
Problems :The world was shocked by the outbreak of a new pneumonia that started in Wuhan, Hubei Province which then spread rapidly to more than 190 countries and territories. This outbreak is named coronavirus disease 2019. The first Covid-19 was reported in Indonesia on March 2, 2020, and March 31, 2020 data shows that there were 1,528 confirmed cases. This pandemic resulted in an increasing number of infected patients and resulted in the need for more intensive nurses and especially in hospitals. Nurses are the health workers who most interact with Covid-19 patients when they are treated at the hospital, this can result in stress related to this situation that has never been experienced at all in Indonesia. Affirmation is a therapy that can be used to reduce the stress level of a nurse's job. The Aim Of The Research:The purpose of this study was to see the effect of affirmation techniques on the work stress level of Covid-19 nurses. Research Method: The design used in this study was quasi-experimental with pre and post test. Data analysis used t-test. The sampling technique in this study was total sampling, the number of samples in this study was 25 respondents, the study was conducted by giving a nurse work stress questionnaire (ENSS) before and after the intervention with affirmation techniques, the intervention was carried out 4 times a week for 4 weeks. The average level of work stress before the intervention was 119.24 with a maximum value of 160 and a minimum value of 93 . The average level of work stress after intervention was 92.92 with a maximum value of 120 and a minimum value of 65 from the data. The Results:The results of the statistical test of the work stress level of Covid-19 nurses before and after the intervention with affirmation techniques obtained $\mathrm{p}$-value $=0,000$. Conclusions: The implication of this research is expected to be applied continuously to maintain the mental health of nurses and to care for Covid-19 patients
\end{abstract}

Keywords :Affirmations, Stress, Covid-19, ENSS

\begin{abstract}
ABSTRAK
Permasalahan: Dunia dikejutkan dengan mewabahnya pneumonia baru yang bermula dari Wuhan, Provinsi Hubei yang kemudian menyebar dengan cepat ke lebih dari 190 Negara dan teritori. Wabah ini diberi nama coronavirus disease 2019. Covid-19 pertama dilaporkan di Indonesia pada tanggal 2 Maret 2020, dan data 31 Maret 2020 menunjukkan kasus yang terkonfirmasi berjumlah 1.528 kasus. Pandemi ini mengakibatkan banyaknya jumlah pasien terinfeksi terus bertambah dan mengakibatkan perlunya perawatan yang lebih intensif dan khusus di Rumah Sakit. Perawat merupakan tenaga kesehatan yang paling banyak berinteraksi dengan pasien Covid-19 ketika di rawat di Rumah Sakit, hal ini dapat mengakibatkan Stress terkait dengan keadaan yang belum pernah sama sekali dialami di Indonesia. Afirmasi adalah salah satu terapi yang dapat di gunakan untuk menurunkan tingkat stress kerja perawat. Tujuan Penelitian: untuk melihat pengaruh teknik afirmasi terhadap tingkat stress kerja perawat Covid-19. Metode Penelitian: desain yang digunakan dalam penelitian ini adalah quasi-eksperimen dengan pre dan post test. Analisa data yang digunakan uji t-Test. Teknik pengambilan sampel pada penelitian ini adalah total sampling, jumlah sampel pada penelitian ini 25 responden, penelitian dilakukan dengan cara memberikan kuesioner stress kerja perawat (ENSS) sebelum dan sesudah di Intervensi dengan teknik Afirmasi, intervensi dilakukan 4 kali seminggu selama 4 minggu.Rata-rata tingkat stress kerja sebelum di intervensi 119,24 dengan nilai maksimal 160 dan nilai minimal 93. Rata-rata tingkat stress kerja sesudah di intervensi 92,92 dengan nilai maksimal 120 dan nilai minimal 65 dari data. Hasil: uji satistik tingkat stress kerja perawat Covid-19 sebelum dan sesudah intervensi dengan teknik afirmasi di dapatkan $p$-value = 0,000. Implikasi.Kesimpulan: penelitian ini diharapkan dapat diterapkan secara terus-menerus guna memepertahakan kesehatan jiwa perawat selama merawat pasien Covid-19.
\end{abstract}

Kata Kunci :Affirmations, Stress, Covid-19, ENS 


\section{PENDAHULUAN}

Kasus virus corona baru (2019-nCov) muncul pertama kali di Wuhan, Cina, dan kemudian WHO menamakan penyakit yang disebabkan virus ini sebagai Covid-19 (WHO, 2020).Covid-19 kemudian berkembang dari endemi menjadi pandemi, serta menyembar kesemua penduduk di banyak Negara di dunia teramasuk di Indonesia.Covid-19 pertama dilaporkan di Indonesia pada tanggal 2 Maret 2020 sejumlah dua kasus.Data 31 Maret 2020 menunjukkan kasus yang terkonfirmasi berjumlah 1.528 kasus dan 136 kasus kematian. Tingkat mortalitas Covid-19 di Indonesia sebesar 8,9\%, angka ini merupakan yang tertinggi di Asia Tenggara. Kejadian ini mengakibatkan kelebihan kapasitas rumah sakit akibat merawat pasein covid dari berbagai daerah dan tempat rujukan.

Rumah sakit merupakan suatu institusi yang fungsi utamanya memberikan pelayanan kesehatan kepada masyarakat.Rumah sakit merupakan salah satu dari sarana kesehatan tempat menyelenggarakan upaya kesehatan.Upaya kesehatan adalah setiap kegiatan untuk memelihara dan meningkatkan kesehatan, bertujuan untuk mewujudkan derajat kesehatan yang optimal bagi masyarakat (Depkes RI, 2009).

Salah satu bagian yang berperan penting dalam meningkatkan kualitas pelayanan kesehatan yaitu pelayanan keperawatan. Pelayanan keperawatan merupakan bagian integral dari pelayanan kesehatan yang mempunyai kontribusi yang besar dalam peningkatan derajat kesehatan, selain itu keperawatan merupakan SDM terbesar di Rumah Sakit yang sangat penting dan strategis (Depkes RI, 2014)

Perawat professional adalah perawat yang memberikan asuhan keperawatan yang berkualitas dalam rangka memenuhi kebutuhan pasien dan untuk mencapai tingkat kesehatan pasien berdasarkan pada standard kompetensi (Simamora, 2008).Perawat professional bertugas dalam berbagai peran, pemberi asuhan keperawatan, pendidik, advokat, konsultan, komunikator, dan sebagai manajer (Potter \& Perry, 2005).

Perawat professional juga harus mampu bekerja di semua unit kerja di rumah sakit dengan berbagai macam pasien dan karkteristik lingkungan kerja yang berbeda (Brunner \& Suddarth, 2002). Menghadapi berbagai karakteristik pasien, tenaga kesehatan lainnya, dan situasi kerja, di tambah dengan keadaan pandemi covid 19 yang terjadi di Indonesia, membuat pelayanan keperawatan di rumah sakit lebih berat dan dapat mengakibatkan stress kerja yang tinggi. National Safety Council (2004) mengungkapkan salah satu jenis pekerjaan yang dianggap paling dapat membuat stress adalah perawat. 
Stres didefinisikan sebagai keadaan tubuh seseorang terhadap situasi dan kondisi yang menimbulkan tekanan, perubahan prilaku, perubahan emosional yang tidak terkontrol, dan lain-lain (Hawari, 2010).Individu yang memiliki emosi positif yang tinggi, akan menimbulkan rasa bahagia, antusias, percaya diri, dan lebih bersemangat dalam melakukan segala aktivitas dibandingakan dengan individu yang memilik emosi positif yang rendah. Individu yang memiliki emosi negatif yang tinggi cenderung memperlihatkan individu yang gugup, penuh dengan rasa bersalah, takut, dan bingung dibandingkan dengan individu yang memilki emosi negatif rendah (Ciccarelli, et all, 2005)

Sherman, et all(2006) mengungkapkan cara untuk membantu seseorang menyadari distorsi pemikiran yang menyebabkan tekanan psikologis, pola prilaku yang salalah dapat diperbaiki dengan Cognitive Behavioral Therapy (CBT), salah satu teknik kognitif terapi adalah teknik Afirmasi (Ah.Y, dkk, 2010).

Teknik Afirmasi merupakan bagian dari terapi kognitif perilaku, yang terdiri dari susunan kata yang disusun baik sebatas pikiran maupun dituangkan dalam tulisan, kemudian di ucapkan berulang-ulang.Adapun afirmasi positif berarti mengarfimasikan kalimat-kalimat positif dengan lantang dan berulang-ulang untuk melawan pemikiran negatif terhadap suatu masalah dari dirinya sendiri, membantu dalam interaksi Intrapersonal dan Interpersonal (Greenberg, at all, 2004).

\section{METODE PENELITIAN}

Desain yang digunakan dalam penelitian ini adalah metode quasi-eksperimen dengan pre dan post test. Analisa data yang digunkan uji t-Test.Penelitian ini dilakukan hanya menggunakan kelompok perlakuan tanpa kelompok kontrol, dengan jumlah sampel 25, teknik pengambilan sampel pada penelitian ini adalah, total sampling, penelitian dilakukan dengan cara memberikan kuesioner stress kerja perawat (ENSS) sebelum dan sesudah di Intervensi dengan teknik Afirmasi, intervensi dilakukan4 kali seminggu selama 4 minggu, Kuesioner terdiri dari 57 pernyataan dengan menggunakan skala likert. Penelitian dilaksanakan di ruang Isolasi Lt.6 (Ruang perawatan Covid-19) di RSUD Siti Fatimah Provinsi Sumsel.

\section{HASIL}

Analisa ini dilakukan untuk memperoleh karakteristik responden. Hasil distribusi tersebut dapat dilihat dari tabel dibawah ini: 
Tabel 1 Distribusi Frekuensi Karakteristik Responden

\begin{tabular}{clcc}
\hline No & \multicolumn{1}{c}{ Variabel } & Jumlah & Persentase \\
\hline 1 & Jenis Kelamin & & \\
& Laki-laki & 8 & $32 \%$ \\
& Perempuan & 17 & $68 \%$ \\
2 & Pendidikan & & \\
& D3 & 20 & $80 \%$ \\
& Ners & 5 & $20 \%$ \\
3 & Lama Kerja & 7 & $28 \%$ \\
& $<1$ th & 18 & $72 \%$ \\
\hline
\end{tabular}

Berdasarkan tabel 1 diatas, diketahui bahwa sebagian besar responden pada penelitian ini berjenis kelamin perempuan (68\%), selanjutnya rerata tingkat pendidikan pada penelitian sebagian besar adalah D3 (80\%), pada variable lama kerja di dominasi oleh perawat dengan pengalaman kerja $\geq 1$ tahun $(72 \%)$.

Tabel 2Distribusi Frekuensi tingkat stress kerja Perawat Covid-19 sebelum dan sesudah Intervensi dengan teknik Afirmasi

\begin{tabular}{ccccc}
\hline No & \multicolumn{1}{c}{ Variabel } & Mean & Min & Maks \\
\hline 1 & $\begin{array}{l}\text { Tingkat stress kerja } \\
\text { Sebelum }(\mathrm{n}=25)\end{array}$ & 119,24 & 93 & 160 \\
2 & $\begin{array}{l}\text { Tingkat stress kerja } \\
\text { Sesudah(n=25) }\end{array}$ & 92,92 & 65 & 120 \\
\hline
\end{tabular}

Berdasarkan standar penilaian intrumen ENSS, semakin tinggi tingkat stress kerja yang dialami perawat, semakin tinggi nilai pengukuran. ENSS tidak memiliki kategori apakah tingkat stress kerja seseorang tergolong rendah, sedang atau tinggi. Dari tabel 2 diatas perhitungan dengan metode transformasi nilai menunjukan bahwa mean tingkat stress kerja sebelum di intervensi memiliki nilai > 100, setelah di intervensi dengan teknik Afirmasi terjadi penurunan mean pada tingkat stress kerja perawat $<100$.

Tabel 3 Perbedaantingkat stress kerja Perawat Covid-19 sebelum dan sesudah Intervensi dengan teknik Afirmasi

\begin{tabular}{clccc}
\hline No & \multicolumn{1}{c}{ Variabel } & Mean & SD & $P$-Value \\
\hline 1 & Tingkat stress kerja & 26,320 & 15.077 & 0,000 \\
& Sebelum dan sesudah $(\mathrm{n}=25)$ & & & \\
\hline
\end{tabular}

Tabel 3 menunjukan nilai mean perbedaan antara tingkat stress kerja sebelum dan sesudah adalah 26,320 dengan standar deviasi 15,077. Hasil uji statistik di dapatkan $p$-value= 0,000. Berdasarkan nilai tersebut dapat disimpulkan bahwa terdapat perbedaan tingkat stress sebelum dan sesudah intervensi teknik afirmasi. 


\section{PEMBAHASAN}

Karakteristik responden pada penelitian ini sesuai dengan gambaran umum perawat yang bekerja di Indonesia.Perawat perempuan lebih dominan dari pada perawat laki-laki, dan tingkat pendidikan yang lebih besar adalah perawat dengan tingkat pendidikan D3.(Hertanto dkk, 2017).Berdasarkan hasil penelitian ini didapatkan bahwa tingkat stress kerja sebelum di intervensi dengan teknik Afirmasi di dapatkan tingkat stress kerja perawat Covid-19>100, dan setelah di intervensi terjadi perubahan mean $<100$.

Perawat, tenaga kesehatan atau relawan yang berpartisifasi dalam membantu memberikan perawatan pasien Covid-19 dapat memberikan berbagai dampak psikologi mulai dari kecemasan, ketakutan ataupun stress kerja. Hasil penelitian (Ike dkk, 2020),tentang kondisi Psikologi relawan bencana Covid-19, mengungkapkan bahwa kecemasan terjadi pada relawan mulai dari tingkat ringan sampai dengan tingkat yang sedang.

Pandemi Covid-19 di Indonesia memberikan dampak psikologis pada tenaga kesehatan yang bekerja di Rumah sakit dan melayani pasien positif Covid-19 yang belum pernah terjadi sebelumnya. Penelitian yang dilakukan oleh (Dede dkk, 2020) yang mengambil sampel 8 kepulauan di Indonesia didapatkan hasil, dari 644 responden, responden tenaga kesehatan di Indonesia mengalami kecemasan, dan tingkat stress pada responden yang merawat pasien Covid-19 sebesar 55\% yag terdiri dari stress ringan sampai dengan stress sangat berat. Keadaan Psikologis ini harus segera diselesaikan dan segera di tindaklanjuti agar tenaga kesehatan dapat memberikan pelayanan yang optimal dan tidak terjadi permasalahan yang lebih besar.

Stress dapat di minimalisir salah satunya dengan menggunakan teknik afirmasi, afirmasi adalah salah satu terapi psikologis yang sangat kuat pengaruhnya terhadap perubahan positif individu (Yanto.A dan Rejeki.S, 2017). Pada penelitian ini peneliti memberikan kata-kata positif untuk memberikan stimulus agar perawat berpikir positif dan menghilangkan pikiran-pikiran negatif yang dapat meningkatkan stress pada perawat.

Sejalan dengan penelitian (Desi \& Ratna, 2017) di dapatkan hasil bahwa ada perbedaan stress dan afek negatip yang signifikan pada saat posttest antara kelompok kontrol dan kelompok perlakuan yang di beri afirmasi dimana terjadi penurunan dibandingkan dengan kelompok kontrol.

Hasil penelitian ini sejalan dengan teori yang menyatakan bahwa tujuan dari latihan afirmasi antara lain melawan pikiran negatif, membantu memvisualisasikan dan menegaskan kepada diri sendiri serta membantu membuat perubahan positif terhadap kehidupan, secara 
khusus juga untuk meningkatkan motivasi, meningkatkan kepercayaan diri, mengontrol perkataan negatif, rasa prustasi, kemarahan serta meningkatkan produktivitas individu.Teknik afrimasi menjadi bagian dari terapi kognitif prilaku, mengajarkan kepada individu tentang cara mengenal suatu keadaan yang sesungguhnya dengan mengubah cara berpikir individu melihat suatu secara lebih seimbang dan terhindar dari dampak negatif dari pikirannya (Sherman, et all, 2014).

Berdasarkan hasil Perbedaan tingkat stress kerja Perawat Covid-19 sebelum dan sesudah intervensi dengan teknik Afirmasi di dapatkan hasil nilai $p<0.05 y$ ang berarti bahwa ada pengaruh teknif Afirmasi terhadap tingkat stress kerja Perawat Sejalan dengan teori afirmasi merupakan suatu cara yang dapat digunakan untuk mengubah cara seseorang berpikir dan merasakan keadaan dirinya. Penggunaan kata-kata positif secara berulang-ulang dan teratur dapat membuat seseorang "memprogram ulang” proses berpikirnya, sikap dan segala sesuatu yang sudah ada pada pikiran bawah sadar, menggantikan hal negatif dengan hal positif (Desi, N dan Ratna, 2017)

Penelitian terkait afirmasi juga dilakukan oleh (Reuwpasha. M. 2014) didapatkan bahwa partisipan yang mendapatkan intervensi afirmasi menunjukan sikap yang lebih positif dan pengontrolan persepsi yang jauh lebih baik dan adanya penurunan tingkat stress dibandingkan kelompok yang tidak diintervensi. Seseorang yang memiliki pandangan positif terhadap diri sendiri memiliki tingkat distress dan efek fisik terhadap stress yang lebih rendah dan kesejahteraan mental yang lebih tinggi. Peningkatan integritas diri juga membantu seseorang untuk menghadapi ancaman dan peristiwa hidup yang menyakitkan dengan lebih adaptif (Sherman \& Cohen, 2006).

\section{KESIMPULAN}

Berdasarkan hasil dan pembahasan pengaruh teknik afirmasi terhadap tingkat stress kerja perawat Covid-19 dapat disimpulkan sebagai berikut : Rata-rata tingkat stress kerja sebelum di intervensi 119,24 dengan nilai maksimal 160 dan nilai minimal 93. Rata-rata tingkat stress kerja sesudah di intervensi 92,92 dengan nilai maksimal 120 dan nilai minimal 65, dari data diatas terlihat penurunan nilai rata-rata tingkat stress kerja sebelum dan sesudah.

Hasil uji satistik tingkat stress kerja perawat Covid-19 sebelum dan sesudah intervensi dengan teknik afirmasi di dapatkan $p$-value $=0,000$,yang berarti bahwa terdapat perbedaan yang bermakna tingkat stress kerja perawat Covid-19 sebelum dan sesudah intervensi dengan teknik afirmasi. 


\section{DAFTAR PUSTAKA}

Ah, Y., Ira, S., \& Pandu, R. 2010. Relaksasi Afirmasi Meningkatkan Self Efficacy pasien kanker Nasofaring. Surabaya: Fakultas Keperawatan Universitas Airlangga.

Amiyanti, L. 2000. Analisa faktor-faktor yang berhubungan dengan stress kerja pada perawat pelaksana di Instalasi Gawat Darurat RSUPN DR. Cipto Mangunkusumo.Tesis tidak dipublikasikan. Jakarta: FIK Universitas Indonesia.

Ciccarelli. Saundra K.,\& Meyer. 2005. Psychology. New Jersey: Pearson Education Inc.

Coon, D. 2001.Psyhology: gateways to mind and Behavior $\left(9^{\text {th }} e d\right)$. USA: Thomson Learning.

Depkes RI, 2009. Undang-Undang Republik Indonesia Nomor 44 Tahun 2009. Rumah Sakit. Lembaran Negara Republik Indonesia Tahun 2009 Nomor 153, Tambahan Lembaran Negara Republik Indonesia Nomor 5072. Jakarta.

Depkes RI. 2014. Undang-Undang Republik Indonesia Nomor 38 Tahun 2014. Keperawatan.Lembaran Negara Republik Indonesia Tahun 2014 Nomor 307, Tambahan Lembaran Negara Republik Indonesia Nomor 5612. Jakarta.

Desi, N., \& Ratna S. 2017. Pengaruh terapi kelompok berbasis afirmasi diri untuk menurunkan tingkat stress dan Afek negatif pada pasien kanker. Semarang: Fakultas Psikologi Universitas Islma Sultan Agung Semarang.

Dwijayanty. 2010. Stress kerja pada perawat pelaksana di ruang rawat inap RS Krakatau Medika tahun 2010. Skripsi tidak dipublikasi. Jakarta: FKM Universitas Indonesia.

Greenberg, J. S., 2004. Comprehensive stress management $\left(8^{\text {th }} e d\right)$. New York: McGraw-Hill Companies.

Hawari, D. 2010. Manajemen stress, cemas, dan depresi. Jakarta: Gaya Baru.

Isaacs, A. 2005.Keperawatan Kesehatan Jiwa \& Psikiatri. Jakarta: EGC.

Jusminar.2012. Gambaran tingkat stress kerja perawat intensive care unit (ICU) di Rumah Sakit Kanker Dharmais.Skripsi. Jakarta: Universitas Indonesia.

Reuwpasha, M. 2014. Pengaruh pelatihan relaksasiafirmasi terhadap kecemasan pada atlit Kempo remaja di KONI Surabaya.Thesis tidak dipublikasikan. Surabaya: Universitas 17 Agustus 1945.

Sherman, D.K., \& Cohen, G.I. 2006. The Psychology of Self-defense: Self-Affirmation theory. In M.P Zasna (Ed.) Advances in Experimental Social Psychology, vol. 38. San Diego, CA : Academik Press hlm. 183-242.

Sherman, D. K. \& Cohen, G. L. 2014. Bridging the partisan divide: Selfaffirmation reduces ideological closed-mindedness and inflexibility in negotiation. Journal of Personality and Social Psychology, 93, 415-430.

Sugiyono. 2015. Metode Penelitian Kuantitatif, Kualitatif, dan R\&D. Bandung: Alfabeta.

Toft, P. G., and J. G. Anderson. 2001. The Nursing stress Scale : Develoment of an Instrument. J. Behavioral Assessment. 3 (1): 11-23.

Yana, Dewi. 2015. Stres kerja pada perawat Instalasi Gawat Darurat di RSUD Pasar Rebo tahun 2014. Jurnal ARSI, 1 (2): 107-115.

Yanto, A., dan Rejeki. S. 2017. Faktor-Faktor yang berhubungan dengan Penurunan Stress kerja perawat baru di Semarang. Nurscope. 3 (1): 1-10. 